\title{
A Novel Environmental Performance Evaluation of Thailand's Food Industry Using Structural Equation Modeling and Fuzzy Analytic Hierarchy Techniques
}

\author{
Anirut Pipatprapa ${ }^{1,+}{ }^{\text {, Hsiang-Hsi Huang }}{ }^{2, *}$ and Ching-Hsu Huang ${ }^{3,+}$ \\ 1 Department of Tropical Agriculture and International Cooperation, National Pingtung University of Science \\ and Technology, No.1 Hseuh-Fu Road, Nei-Fu, Pingtung 912, Taiwan; anirut87@hotmail.com \\ 2 Department of Industrial Management, National Pingtung University of Science and Technology, \\ No.1 Hseuh-Fu Road, Nei-Fu, Pingtung 912, Taiwan \\ 3 Department of Hotel and Restaurant Management, National Pingtung University of Science and Technology, \\ No.1 Hseuh-Fu Road, Nei-Fu, Pingtung 912, Taiwan; chinghsu@mail.npust.edu.tw \\ * Correspondence: hhuang@mail.npust.edu.tw; Tel.: +886-8-770-3202 (ext. 7665); Fax: +886-8-774-03211 \\ + These authors contributed equally to this work.
}

Academic Editor: Tin-Chih Toly Chen

Received: 29 October 2015; Accepted: 2 March 2016; Published: 8 March 2016

\begin{abstract}
Currently, the environment and sustainability are important topics for every industry. The food industry is particularly complicated in this regard because of the dynamic and complex character of food products and their production. This study uses structural equation modeling (SEM) and a fuzzy analytic hierarchy process (FAHP) to investigate which factors are suitable for evaluating the environmental performance of Thailand's food industry. A first-stage questionnaire survey was conducted with 178 managers in the food industry that obtained a certificate from the Department of Industrial Work of Thailand to synthesize the performance measurement model and the significance of the relationship between the indicators. A second-stage questionnaire measured 18 experts' priorities regarding the criteria and sub-factors involved in the different aspects and assessment items regarding environmental performance. SEM showed that quality management, market orientation, and innovation capability have a significantly positive effect on environmental performance. The FAHP showed that the experts were most concerned about quality management, followed by market orientation and innovation capability; the assessment items for quality policy, quality assurance, and customer orientation were of the most concern. The findings of this study can be referenced and support managerial decision making when monitoring environmental performance.
\end{abstract}

Keywords: environmental performance; structural equation modeling; fuzzy analytic hierarchy process

\section{Introduction}

Environmental and climate change issues are part of sustainable development. A continuously expanding awareness of environmental issues has become increasingly obvious $[1,2]$. In recent decades, public concern has become the driver of the increasing pressure that is forcing various industries to improve the environmental performance of their products and activities [1,3]. The food industry is particularly and directly affected by climate change (i.e., because of flooding, droughts, and temperature change). Simultaneously, the food industry also causes environmental problems, such as those involving waste water, solid waste, and air pollution [4]. The waste or environmental problems in the food industry are generated over the entire product life cycle (i.e., extraction of raw materials, design and production, packaging and distribution, use and maintenance, reuse and recycling, and 
disposal) [5]. A proper management system should be employed to prevent and reduce service environmental problems [4].

The food industry is an important contributor to Thailand's economy. The national economics and social development board (NESDB) [6] found that the food manufacturing industry has been expanding continuously and increasing rapidly, growing by 26.48 percent over the 1990-2014 period. The food industry is strongly supported by the Thai government, which helps reduce pressures and constraints at the global level and promotes Thai food as a global cuisine. Many projects are designed to develop and exploit competitive advantages in the food industry through sustainable development concepts, including (1) the National Food Institute, which assists processors in implementing management systems such as GMP (Good Manufacturing Practice), HACCP (Hazard Analysis Critical Control Point), ISO (International Organization for Standardization), and systems to recognize organizations or companies that are fulfill required abilities to perform food processing and running business [7]; (2) food production development and increasing the competitiveness of the country's halal food industry in conjunction with the Halal Standard Institute [7]; and (3) Thailand's Ministry of Industry's green industry regulation, which assesses green system processes in various industries by means of sustainable and balanced development in the social, economic, innovative/creative and environmental spheres $[8,9]$.

Nonetheless, the Thai government seems to have prioritized economic growth at the expense of environmental sustainability [10]. The NESDB [6] reported that Thailand's GDP has expanded continuously from US $\$ 207.09$ billion to US $\$ 373.8$ billion over the 2006-2014 period; in 2015, the GDP growth rate increased 2.9 percent over the previous year. The most important component of Thai GDP is manufacturing, which accounts for approximately 34 percent of GDP. The climate change performance results in 2016 [11] indicated that Thailand's GDP, population, and $\mathrm{CO}_{2}$ emissions have consistently increased and that Thailand scored 48.16 lower than in previous years and ranked 48th among the 61 countries measured. Thus, the Thai government's attempts to reduce environmental problems through its national climate policy have proven inadequate. Approximately 54.43 percent of $\mathrm{CO}_{2}$ emissions were generated by the manufacturing industry and by electricity and heat production.

As discussed above, environmental management clearly remains an important problem for the Thai food industry and for sustainable development in general. Moreover, the international pressures linked to global and regional environmental concerns are affecting environmentally sensitive domestic markets $[12,13]$.

The literature is replete with authors who have devised various criteria for evaluating environmental performance, such as management systems [14-16], product development processes [17], product development using life cycle assessment [18-20], internal organizations [21], marketing bases [22], and supply chains [23,24]) Moreover, it cannot be assumed that the factors affecting environmental performance have the same effects in all cases. These factors should thus be measured not separately but rather as part of a multi-dimensional approach that considers all factors simultaneously. We could not find any study that integrated the concepts of quality management, market orientation, and innovation capability to evaluate environmental performance in the food industry context. This study is the first study that attempt to integrate structural equation modeling (SEM) and a fuzzy analytic hierarchy process (FAHP) to measure the environmental performance of Thailand's food industry. The reason for combining the SEM and FAHP approaches in this study are as follows: (1) SEM analyzes relatively new phenomena based on theory and measures the relationship between variables from the literature or those without theoretical support [25]. Thus, we employ SEM to define the criteria and sub-criteria and confirm the influence of quality management, market orientation, and innovation capability on environmental performance. (2) FAHP can support decision makers in making choices relevant to their goals and targets. Moreover, FAHP also can reduce the problem of ambiguity. Thus, in this study, FAHP is used to assign weights and ranks between various decision elements.

This paper is structured as follows. The second section reviews the literature on SEM and FAHP. The third section discusses the critical factors of environmental performance measurement. The fourth 
section addresses our methodology; in addition to detailed information on the instrument, data collection, and target population, this fourth section also explains the choices of SEM and FAHP. The final section presents our results and conclusions.

\section{Literature Review}

\subsection{Structural Equation Modeling}

Structural equation modeling (SEM) is a statistical technique that tests and estimates causal relations using a combination of statistical data and qualitative causal assumptions. The goal of SEM analysis is to determine the extent to which a theoretical proposition is supported by sample data. If the sample data support the theoretical model, then more complex theoretical models can be hypothesized. If the sample data do not support the theoretical model, then either the original model can be modified or a new theoretical model must be developed. Thus, SEM was developed to examine critical factors by following an explanatory approach to testing hypotheses and employing a form of covariance analysis that allows for the testing of hypotheses regarding the causality among observed and latent variables. Moreover, SEM does not have limitations regarding the number of variables and can address multiple dependent variables and estimate multiple equations simultaneously, whereas linear regression techniques can estimate only one equation at a time [26]. This study uses SEM as its theoretical model in an empirical analysis of the effects of quality management, market orientation, and innovation capability on environmental performance. SEM contains both a measurement model and a path model. The measurement model focuses on the relationship between the latent variable and the observed variable, such as the relationship between quality management and quality assurance, as well as others. The path model addresses the relationship between the latent variables, such as the relationship between quality management and environmental performance $[27,28]$.

\subsection{Fuzzy Analytic Hierarchy Process}

FAHP is designed for situations in which ideas, feelings, and emotions affecting the decision process can be quantified using a numerical scale that prioritizes alternatives [29]. Chang [30] proposed the extent analysis method, which is the most commonly used method in the set of FAHP applications. In this method, a fuzzy number is used to quantify the "extent". In the extent analysis of each object, a fuzzy synthetic degree value can be obtained based on the fuzzy values. $X=\left(x_{1}, x_{2}, \ldots, x_{n}\right)$ represents an element of the alternative as an object set. In addition, the elements of the criteria as a goal set are represented by $U=\left(u_{1}, u_{2}, \ldots, u_{m}\right)$. Each object is taken, and the extent analysis for each goal, called $\mathrm{g}_{\mathrm{i}}$, is then performed. Consequently, the extent analysis values for each object, $\mathrm{m}$, can be obtained by solving the Formula (1) [31-33] as follows:

$$
M_{g_{1}}^{1} M_{g_{2}}^{2} \ldots \ldots, M_{g_{i}}^{m} ; i=1,2,3, \ldots, \mathrm{n}
$$

where $M_{g_{i}}^{j}$ is triangular fuzzy number that can be demonstrated by $l, \mathrm{~m}$, and $u$, which are values in which $\mathrm{m}$ represents the most promising value and $l$ and $u$ represent the smallest and the largest possible values, respectively. All the $M_{g_{i}}^{j}, j=1,2,3, \ldots, \mathrm{m}$ are triangular fuzzy numbers (TFNs). The steps of Chang's extent analysis are described as follows [34]:

Step 1: The comparison fuzzy matrix can be represented as [35]:

$$
\tilde{A}=\left[\begin{array}{cccc}
\left(a_{11}^{l}, a_{11}^{m}, a_{11}^{u}\right) & \left(a_{12}^{l}, a_{12}^{m}, a_{12}^{u}\right) & \ldots & \left(a_{1 n}^{l}, a_{1 n}^{m}, a_{1 n}^{u}\right) \\
\left(a_{21}^{l}, a_{21}^{m}, a_{21}^{u}\right) & \left(a_{22}^{l}, a_{22}^{m}, a_{22}^{u}\right) & & \left(a_{2 n}^{l}, a_{2 n}^{m}, a_{2 n}^{u}\right) \\
\vdots & \vdots & \ddots & \vdots \\
\left(a_{m 1}^{l}, a_{m 1}^{m}, a_{m 1}^{u}\right) & \left(a_{m 2}^{l}, a_{m 2}^{m}, a_{m 2}^{u}\right) & \ldots & \left(a_{m n}^{l}, a_{m n}^{m}, a_{m n}^{u}\right)
\end{array}\right]
$$


The element $\tilde{a}_{m n}$ that is given by $\left(a_{m n}^{l}, a_{m n}^{m}, a_{m n}^{u}\right)$ represents the comparison of the component $\mathrm{m}$ with the component $\mathrm{n}$. Due to the operational law of fuzzy numbers, the matrix $\tilde{A}$ can be rewritten by replacing $\tilde{a}_{m n}$ with the corresponding reciprocal values as [36]:

$$
\widetilde{A}=\left[\begin{array}{cccc}
(1,1,1) & \left(a_{12}^{l}, a_{12}^{m}, a_{12}^{u}\right) & \ldots & \left(a_{1 n}^{l}, a_{1 n}^{m}, a_{1 n}^{u}\right) \\
\left(\frac{1}{a_{21}^{u}}, \frac{1}{a_{21}^{m}}, \frac{1}{a_{21}^{l}}\right) & (1,1,1) & & \left(a_{2 n}^{l}, a_{2 n}^{m}, a_{2 n}^{u}\right) \\
\vdots & \vdots & \ddots & \vdots \\
\left(\frac{1}{a_{m 1}^{u}}, \frac{1}{a_{m 1}^{m}}, \frac{1}{a_{m 1}^{l}}\right) & \left(\frac{1}{a_{m 1}^{u}}, \frac{1}{a_{m 1}^{m}}, \frac{1}{a_{m 1}^{l}}\right) & \ldots & (1,1,1)
\end{array}\right]
$$

Step 2: The value of the fuzzy synthetic extent is defined as follows:

$$
S_{i}=\sum_{j=1}^{m} M_{g_{i}}^{j} \otimes\left[\sum_{i=1}^{n} \sum_{j=1}^{m} M_{g_{i}}^{j}\right]^{-1}
$$

If $M_{g_{i}}^{j}=\left(a_{i j}, b_{i j}, c_{i j}\right)$, then $\sum_{j=1}^{m} M_{g_{i}}^{j}$ with the fuzzy addition operation of $\mathrm{m}$ extent analysis values for a particular matrix is defined as:

$$
\sum_{j=1}^{m} M_{g_{i}}^{j}=\left[\sum_{j=1}^{m} l_{j}, \sum_{j=1}^{m} m_{j}, \sum_{j=1}^{m} u_{j}\right] \text { and } \sum_{i=1}^{n} \sum_{j=1}^{m} \widetilde{M}_{g_{i}}^{j}=\left[\sum_{i=1}^{m} l_{i}, \sum_{i=1}^{m} m_{i}, \sum_{i=1}^{m} u_{i}\right]
$$

Then, the fuzzy addition operation is performed:

$$
\left[\sum_{i=1}^{n} \sum_{j=1}^{m} M_{g_{i}}^{j}\right]^{-1}=\left[\frac{1}{\sum_{i=1}^{n} u_{j}} \frac{1}{\sum_{i=1}^{n} m_{j}} \frac{1}{\sum_{i=1}^{n} l_{j}}\right]
$$

Thus:

$$
S_{i}=\sum_{j=1}^{m} \widetilde{M}_{g_{i}}^{j} \otimes\left[\sum_{i=1}^{n} \sum_{j=1}^{m} \widetilde{M}_{g_{i}}^{j}\right]^{-1}
$$

Step 3: Possibility degree calculation: if $\widetilde{M}_{1}=\left(a_{1}, b_{1}, c_{1}\right), \widetilde{M}_{2}=\left(a_{2}, b_{2}, c_{3}\right)$ then the possibility degree of $\widetilde{M}_{1} \geqslant \widetilde{M}_{2}$ that is indicated by $\mathrm{V}\left(\widetilde{M}_{1} \geqslant \widetilde{M}_{2}\right)$ is defined as follows:

$$
\mathrm{V}\left(\widetilde{M}_{1} \geqslant \widetilde{M}_{2}\right)=\sup \left[\min \left(\widetilde{M}_{1}(x), \widetilde{M}_{2}(y)\right)\right]
$$

and can be equivalently expressed as follows:

$$
\mathrm{V}\left(\widetilde{M}_{1} \geqslant \widetilde{M}_{2}\right)=\operatorname{hgt}\left(\widetilde{M}_{1} \cap \widetilde{M}_{2}\right)=\widetilde{M}_{2}(d)=\left[\begin{array}{ccc}
1 & \text { if } m_{2} \geqslant m_{1} \\
0 & \text { if } l_{1} \geqslant u_{2} \\
\frac{l_{1}-u_{2}}{\left(m_{2}-u_{2}\right)-\left(m_{1}-l_{1}\right)} & \text {,otherwise }
\end{array}\right]
$$

where $d$ is the ordinate of the highest intersection point between $\mu_{\tilde{M}_{1}}, \mu_{\tilde{M}_{2}}$ (see Figure 1). 


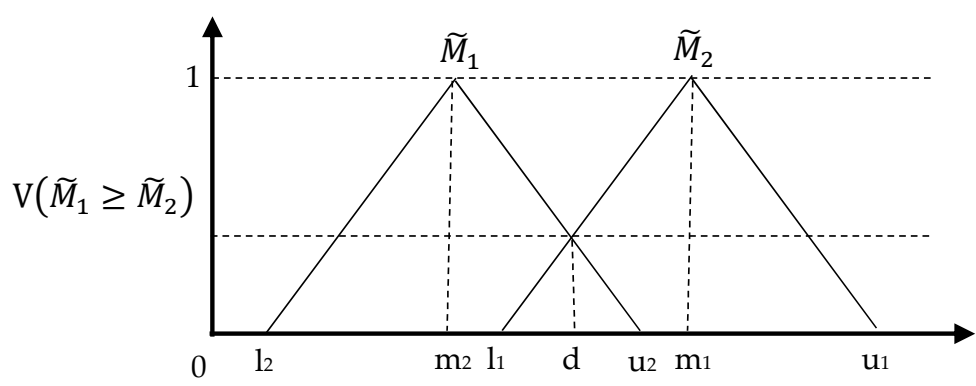

Figure 1. Possibility Degree of $\widetilde{M}_{1} \geqslant \widetilde{M}_{2}$.

Step 4: The degree of possibility that a convex fuzzy number to be greater than $k$ convex fuzzy numbers can be defined by:

$$
V\left(\widetilde{M} \geqslant \widetilde{M}_{1}, \widetilde{M}_{2}, \ldots, \widetilde{M}_{k}\right)=\min V\left(\widetilde{M} \geqslant \widetilde{M}_{i}\right) i=1,2,3, \ldots, k .
$$

If it is assumed that for $\left(k=1,2, \ldots, \mathrm{n} ; k \neq I\right.$, and $\mathrm{d}^{\prime}\left(A_{i}\right)=\min \mathrm{V}\left(\widetilde{M}_{1} \geqslant \widetilde{M}_{2}\right)$ then the weight vector is given by:

$$
W^{\prime}=\left(d^{\prime}\left(A_{1}\right), d^{\prime}\left(A_{2}\right), \ldots, d^{\prime}\left(A_{n}\right)\right)^{t}
$$

Step 5: Via normalization, the normalized weight vectors are defined as:

$$
W=\left(d\left(A_{1}\right), d\left(A_{2}\right), \ldots, d\left(A_{n}\right)\right)^{t}
$$

where $W$ is a non-fuzzy number that gives the priority weights of one alternative over another.

Step 6: Solve the fuzzy eigenvalue. A fuzzy eigenvalue, $\tilde{\lambda}$ is a fuzzy number solution to:

$$
\tilde{A}_{\tilde{x}}=\tilde{\lambda}_{\tilde{x}}
$$

where $\widetilde{\lambda}_{\text {max }}$ is the largest eigenvalue of $\widetilde{A}$, and $\tilde{X}$ is non-zero $\mathrm{n} \times 1$, a fuzzy vector containing fuzzy number $\tilde{X}_{i}$. To perform fuzzy multiplications and additions by using the interval arithmetic and $\alpha$-cut, the equation $\widetilde{A}_{\widetilde{x}}=\tilde{\lambda}_{\widetilde{x}}$ is equivalent to:

$$
\left[a_{i 1 l}^{\alpha} x_{1 l}^{\alpha}, a_{i 1 u}^{\alpha} x_{1 u}^{\alpha}\right] \otimes \ldots \otimes\left[a_{i n l}^{\alpha} x_{n l}^{\alpha}, a_{i n u}^{\alpha} x_{n u}^{\alpha}\right]=\left[\lambda x_{i l}^{\alpha}, \lambda x_{i u}^{\alpha}\right]
$$

where

$$
\begin{gathered}
\tilde{A}=\left[\tilde{a}_{i j}^{\alpha}\right], \tilde{x}^{t}=\left(\tilde{x}_{1}, \ldots, \tilde{x}_{n}\right) \\
\tilde{a}_{i j}^{\alpha}=\left[a_{i j l}^{\alpha}, a_{i j u}^{\alpha}\right], x_{i j}^{\alpha}=\left[x_{i l}^{\alpha}, x_{i u}^{\alpha}\right], \tilde{\lambda}^{a}=\left[\lambda_{l}^{\alpha}, \lambda_{u}^{\alpha}\right]
\end{gathered}
$$

for $0<\alpha \leqslant 1$ and all $i, j$, where $i=1,2, \ldots, \mathrm{n}, j=1,2, \ldots, \mathrm{n}$. The a-cut is known to incorporate the expert's or decision maker's confidence over his/her preferences. The degree of satisfaction for the judgment matrix $\widetilde{A}$ is estimated by the index of optimism $\mu$. A larger value of index $\mu$ indicates a higher degree of optimism. The index of optimism is a linear convex combination defined as:

$$
\tilde{a}_{i j}^{\alpha}=\mu a_{i j l}^{\alpha}+(1-\mu) a_{i j l}^{\alpha}, \forall \alpha \epsilon[0,1]
$$

When $\alpha$ is fixed, the following matrix can be obtained after setting the index of optimism, $\mu$, to estimate the degree of satisfaction:

$$
\widetilde{A}=\left[\begin{array}{cccc}
\widetilde{a}_{11}^{\alpha} & \widetilde{a}_{12}^{\alpha} & \ldots & \widetilde{a}_{1 n}^{\alpha} \\
\widetilde{a}_{21}^{\alpha} & \widetilde{a}_{22}^{\alpha} & \ldots & \widetilde{a}_{n 1}^{\alpha} \\
\cdot & \cdot & \cdot & \cdot \\
\cdot & \cdot & \cdot & \cdot \\
\cdot & \cdot & \cdot & \cdot \\
\widetilde{a}_{n 1}^{\alpha} & \tilde{a}_{n 2}^{\alpha} & \cdots & \widetilde{a}_{n n}^{\alpha}
\end{array}\right]
$$


The eigenvector is calculated by fixing the $l$ value and identifying the maximal eigenvalue. To control the results of this method, the consistency ratios (ConRs) of each matrix and the overall inconsistency of the hierarchy are calculated. ConR is used to directly estimate the consistency of the pairwise comparisons. If ConR $\leqslant 0.1$, the level of inconsistency is acceptable. Otherwise, the inconsistency is high, and the decision maker(s) may need to revise the estimate of the element $a_{i j}$ to obtain better consistency $[37,38]$.

\section{The Factors of Environmental Performance Measurement}

Based on a study of the previous literature and research, this study summarizes the following criteria to measure environmental performance. The hypotheses are formulated on the basis of the criteria obtained as follows.

\subsection{Quality Management}

To be successful in the global marketplace over the long run, organizations must operate based on effective quality management principles. Many previous studies have emphasized the need for an appropriate quality management system to avoid failures in production operations and inappropriate methods of design, control, implementation and improvement. Quality management in the food industry is particularly complicated because it involves the complex characteristics of food and their raw materials resulting from the variability of restricted shelf life. This study adopted the Luning and Marcelis [39] model of quality management designed for the food industry. Quality management consists of the following: (1) quality assurance, which addresses setting requirements in the quality system, evaluating and organizing change and making consumers confident that quality requirements will be met; (2) quality improvement, a systematic approach to improving a system by paying attention to structural causes and solutions; (3) quality design as a method to translate the voice of the customer into the technical requirements of products and processes; (4) quality control as a basic activity of food quality management to control variation within tolerable levels by taking corrective actions, while understanding that statistical process control, acceptance sampling, and visual inspection are used in quality control; and (5) a quality policy that determines long-term quality goals and objectives and how to achieve the same results through quality systems [40,41].

This section discusses how environmental performance is affected by quality management. Notably, numerous studies have demonstrated that quality management has positive and significant effects on environmental performance [1,42-49].

Based on the discussion above, this study develops the following hypotheses to investigate how quality management influences environmental performance.

$\mathrm{H}_{1}$ : Quality management has a positive significant impact on environmental performance.

\subsection{Market Orientation}

Contemporary customers expect increasingly higher levels of product or service quality than they have in the past because they have more choices for product/service offerings. It is a great challenge for businesses to remain competitive by satisfying customers, which is the underlying philosophy of marketing. Market-oriented organizations typically have a long-term focus related to profits and to implementing a high degree of market-oriented activities. To grow and survive in a competitive environment, these organizations must focus on long-term investment strategies that are important to building market orientation. Market orientation builds on the same foundations as the market concept, as that concept has three facets: customer orientation, competitor orientation, and inter-functional coordination. These three facets can be better described as follows: (1) customer orientation implies that companies must have intensive knowledge and understanding of customer needs, demands and expectations, which is the underlying philosophy of marketing; (2) competitor orientation posits that organizations should identify, analyze and use the strengths, weaknesses, opportunities, and threats of current and future competitors, in addition to focusing on integrated 
marketing, which means that all marketing efforts of the company are in sync and support one another; and (3) inter-functional coordination, which means that all the departments within a company play a critical role in satisfying customers, in addition to providing adequate business process and systems for data input and coordinating the communication of disseminated activities to create value for the customer. This study defined marketing implementation as market orientation by following the conception of marketing implementation by Slater and Narver [50].

To understand the relationship between market orientation and environmental performance, the results of (Charles et al. [51], Kuma et al. [52], Chen et al. [53]) showed that market orientation has a strong and direct effect on environmental performance. Thus, this study proposes its three research hypotheses:

$\mathrm{H}_{2}$ : Market orientation has a positive, significant impact on environmental performance.

\subsection{Innovation Capability}

The term innovation capability has been defined in several ways. Lawson and Samson [54] described it as "the ability to continuously transform knowledge and ideas in new products, processes and systems for the benefit of the firm and its stakeholders". Furthermore, innovation capability is also understood as the implementation or creation of technology as applied to systems, policies, programs, devices, or services that are new to an organization [55]. For the competitor dimension, competitors apply the collective knowledge, skills, and resources to innovation activities related to new products, processes, services or management systems to create and add value for their firms $[56,57]$. According to the earlier literature, the concept of innovation capability includes three elements: (1) process innovation, which consists of practices, procedures, and activities that take ideas through to concepts, then though development to commercialization; (2) knowledge and competency, which consists of the associated management requirements for knowledge, competencies, and technology; and (3) organizational support, which is necessary to support the process and knowledge requirements for innovation. Furthermore, the attributes of innovation capability are considered by (Chiou et al. [45], Cheng et al. [58], Sezen et al. [59], Ar [60]) as critical factors that influence the effects on environmental performance. Based on the above, the following research hypothesis is formulated as follows:

$\mathrm{H}_{3}$ : Innovation capability has a positive, significant impact on environmental performance.

\subsection{Environmental Performance}

Numerous studies have been conducted to investigate the effectiveness of the adoption of environmental management systems. Various assessment methodologies have evaluated the effects of management systems on environmental performance [5,61]. Furthermore, international standards for environmental performance evaluation are key elements that are designed to evaluate an organization's environmental performance by transforming new data into legible, easily understood information. In this study, we adopted the environmental performance indicators from ISO14031, which identified two types of indicators as follows [62,63]: (1) operational performance is an indicator that provides information about the environmental performance of an organization's operations, such as materials, energy, and services, which thus supports the organization's operations, and (2) environmental condition is an indicator that provides information regarding the direct effects of the organization's operations on the environment, which is particularly difficult to standardize or operationalize as local, regional, rational or global conditions of the environment. Based on the literature discussed above and on our hypotheses, a model of relations was formed (Figure 2), which showed the relationship between quality management, market orientation, and innovation capability on environmental performance. 


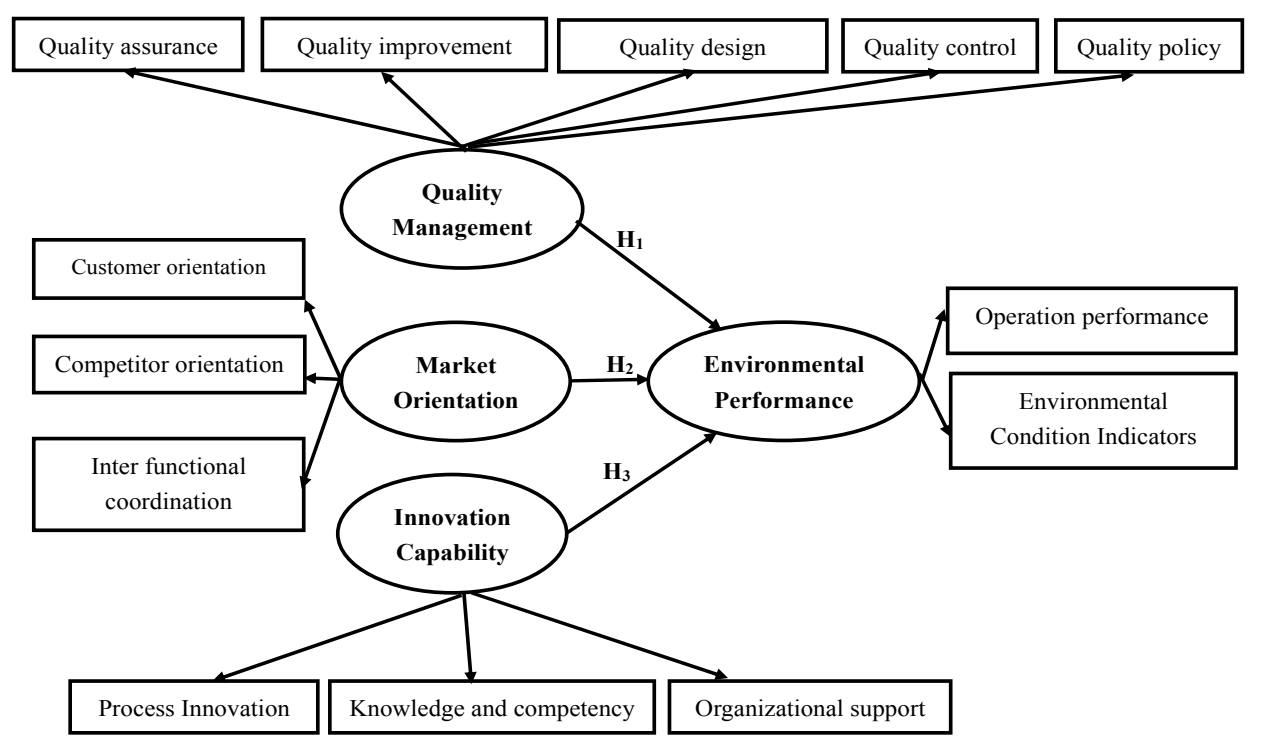

Figure 2. Hypotheses' framework.

\section{Methodology}

This study integrates SEM and FAHP to investigate criteria and factors affecting environmental performance and creates proper criteria to assess environmental performance in Thailand's food industry. The implementation stage of this study is represented in Figure 3.

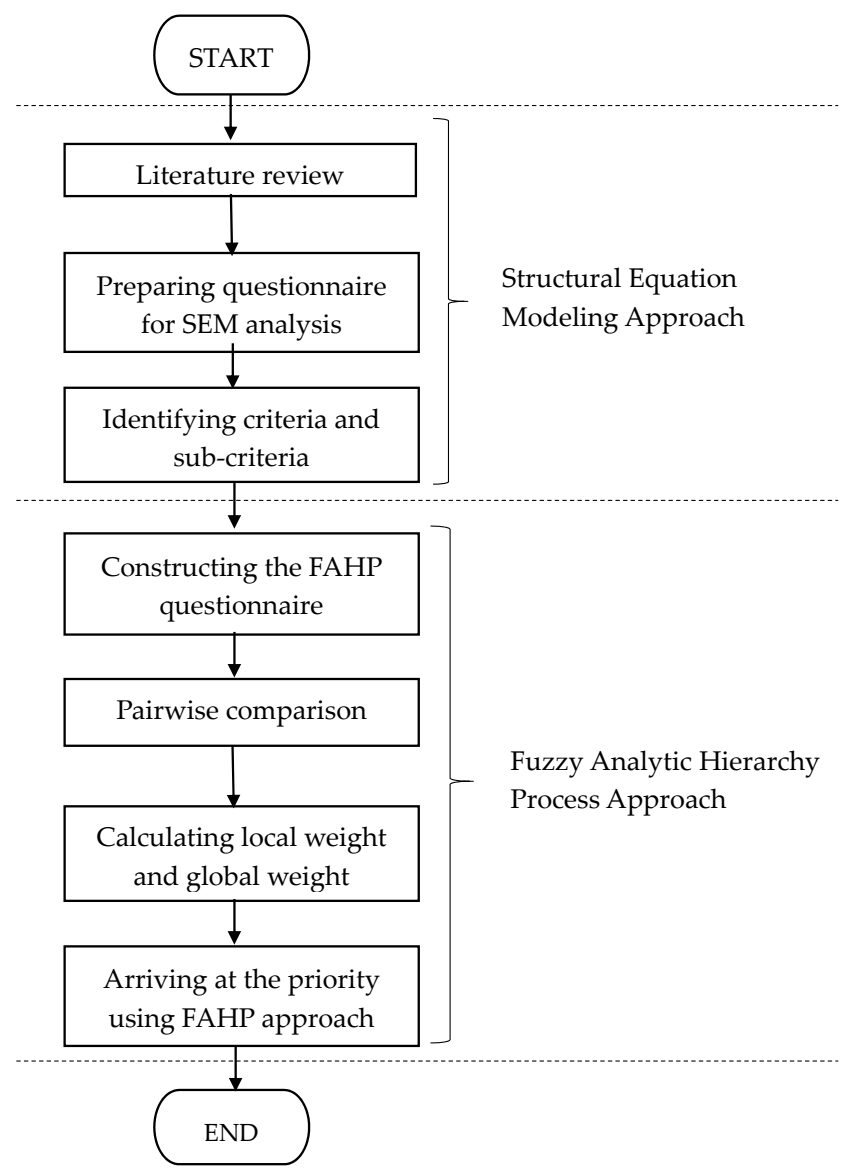

Figure 3. The research methodology algorithm. 


\subsection{Structural Equation Modeling Approach}

The SEM approach was used to identify the relationship among criteria (latent variables) and sub-criteria (observed variables) and to test the underlying construct in the proposed model that tests environmental performance in Thailand's food industry. The reasons for applying the SEM approach to identify factors are as follows: (1) SEM is not difficult to use to test the hypotheses and (2) SEM does not limit the number of variables (i.e., latent variables and observed variables); that is, it can handle and estimate multivariate relations or indirect effects that are not easily implemented elsewhere [64]. According to Phan and Baird [65], Teo et al. [66], and Innami and Koizumi [64], the SEM analysis consists of a two-stage process; in addition, these authors (1) assessed measurement models to address the relationship between an observed variable and a latent variable and (2) evaluated structured models, emphasizing the relationship between latent constructs and specifying how the constructs affect one another.

Stage 1: Assessing the measurement model

The first questionnaire was developed to test the hypothesized model. The questionnaire consisted of 4 sections: (1) quality management, (2) market orientation, (3) innovation capability, and (4) environmental performance. In total, 70 measurement scale items were employed to evaluate the proposed model. All the questionnaire items were selected from published literature related to evaluating environmental performance. A seven-point Likert scale $(1=$ "strongly disagree" to 7 = "strongly agree") was employed to measure items for quality management, market orientation, and innovation capability. Environmental performance was estimated by using a seven-point Likert scale $(1=$ "not at all important" to $7=$ "extremely important"). The respondents were presidents and managers in Thailand's food industries, and these respondents had obtained a green certificate from the Department of Industrial Work. In gathering data, we employed multiple methods to administer the quantitative survey research (i.e., a mail survey, an internet survey, and a self-administered survey). The questionnaires were distributed to 300 food industry firms in Thailand, which resulted in 178 respondents, for a valid response rate of 59.33 percent. In terms of respondent position, approximately 88.20 percent of the respondents came from firms with 157 managers, and 11.79 percent were from firms with 21 chief executive managers.

The reliability and validity of this research instrument was tested to ensure the adequacy and feasibility of the model. Confirmatory factor analysis was used to evaluate the measurement model. Further evidence of its reliability and validity are provided in Table 1, which presents the standard estimate values, Cronbach's alpha, and average variance extracted scores of different factors' obtained (AVE), composite reliability (CR), and inter-construct correlation values. The reliabilities of the individual dimensions ranged from 0.791 to 0.918 , which exceeds the recommended level of $0.7[53,67,68]$. The AVE of all the latent variables was greater than the acceptable limit of 0.5 , which further supports the convergent validity of the construct. CR for all the factors was greater than 0.7 , which is acceptable, and the square roots of the AVE values for all the factors are greater than that of the inter-construct correlations, which supports the discriminant validity of the constructs. In addition, the measurement model reflects good construct validity $[27,28]$.

Stage 2: Assessing the structural model

The structural model fit using SEM to draw relationships among independent and dependent variables can be demonstrated, even when a dependent variable becomes an independent variable in other relationships. SEM is a statistical methodology that takes a confirmatory (i.e., hypothesis-testing) approach to the analysis of structural theory with the same phenomenon. Typically, this theory represents a "causal" process that generates observations for multiple variables. The model will be formulated using three criteria: quality management, market orientation, and innovation capability. The acceptable standards of goodness-of-fit were as follows: (1) $1.0<c^{2} / d f<2.0$; (2) Goodness-of-fit index (GFI) > 0.95; (3) Adjusted goodness-of-fit index (AGFI) > 0.80; (4) Comparative fit index $(\mathrm{CFI})>0.90$; (5) Increment fit index (IFI) > 0.90; and (6) Toot mean square error of approximation (RMSEA) $<0.10$. These items can be aggregated into a composite score for subsequent analysis $[27,28]$. 
Table 1. Measurement model results.

\begin{tabular}{|c|c|c|c|c|c|c|}
\hline Construct & $\begin{array}{l}\text { Measurement } \\
\text { Items }\end{array}$ & $\begin{array}{l}\text { Standard } \\
\text { Estimates }\end{array}$ & $\begin{array}{c}\text { Cronbach's } \\
\text { Alpha }\end{array}$ & AVE & CR & $\begin{array}{c}\text { Inter Construct } \\
\text { Correlation }\end{array}$ \\
\hline \multirow{2}{*}{$\begin{array}{l}\text { Environmental } \\
\text { performance }\end{array}$} & EP1 & 0.914 & 0.918 & \multirow{2}{*}{0.716} & \multirow{2}{*}{0.833} & \multirow{2}{*}{0.688} \\
\hline & EP2 & 0.772 & 0.904 & & & \\
\hline \multirow{5}{*}{$\begin{array}{c}\text { Quality } \\
\text { management }\end{array}$} & QM1 & 0.563 & 0.854 & \multirow{5}{*}{0.608} & \multirow{5}{*}{0.884} & \multirow{5}{*}{0.678} \\
\hline & QM2 & 0.851 & 0.822 & & & \\
\hline & QM3 & 0.842 & 0.791 & & & \\
\hline & QM4 & 0.775 & 0.867 & & & \\
\hline & QM5 & 0.830 & 0.842 & & & \\
\hline \multirow{3}{*}{ Market orientation } & MO1 & 0.828 & 0.882 & \multirow{3}{*}{0.693} & \multirow{3}{*}{0.731} & \multirow{3}{*}{0.694} \\
\hline & $\mathrm{MO} 2$ & 0.837 & 0.882 & & & \\
\hline & $\mathrm{MO} 3$ & 0.833 & 0.811 & & & \\
\hline \multirow{3}{*}{$\begin{array}{l}\text { Innovation } \\
\text { capability }\end{array}$} & IC1 & 0.752 & 0.834 & \multirow{3}{*}{0.607} & \multirow{3}{*}{0.822} & \multirow{3}{*}{0.745} \\
\hline & IC2 & 0.766 & 0.856 & & & \\
\hline & IC3 & 0.818 & 0.866 & & & \\
\hline
\end{tabular}

\subsection{Fuzzy Analytic Hierarchy Approach}

Stage 1: Constructing the FAHP questionnaire

The second questionnaire was developed from SEM analysis results for analyzing pair-wiseto analyze pairwise comparison matrices. We proposed 13 construct items that define three criteria (quality management, market orientation, and innovation capability) affecting environmental performance. The sub-criteria consisted of quality design (QM1), quality policy (QM2), quality assurance (QM3), quality control (QM4), quality improvement (QM5), customer orientation (MO1), competitor orientation (MO2), inter-function orientation (MO3), process innovation (IC1), knowledge and competency (IC2), and organizational support (IC3). A nine -point Likert scale was used to compare among the criteria, and the scale ranged from $1=$ "Equally important" to $9=$ "Extremely important". Self-administered survey and interview completion techniques were used to collect data from experts in the food industry (i.e., professional and academic), which resulted in 18 experts.

Stage 2: Pairwise comparison matrix

We determined the local weights of the factors and sub-factors using pairwise comparison matrices. Based on the distribution, the parameters are tocan be determined. In this study, we used triangular distribution. The TFNs $\tilde{1}$ to $\widetilde{9}$ arewere used to improve the nine-point scaling scheme [32]. The reason for using TFNs in this study is that they are a suitable tool for formulating decision problems and modeling decision makers' vague and incomplete judgments. Moreover, it is easy and convenient for experts or decision makers to apply and calculate the criteria weight and normalization [32,67-70]. The scales and related TFNs are shown in Table 2.

Table 2. The linguistic scale and corresponding triangular fuzzy numbers.

\begin{tabular}{ccc}
\hline Fuzzy Number & Linguistic Scales & Scale of Fuzzy Number \\
\hline$\widetilde{1}$ & Equally important & $(1,1,1)$ \\
$\widetilde{3}$ & Weakly important & $(2,3,4)$ \\
$\widetilde{5}$ & Essentially important & $(4,5,6)$ \\
$\widetilde{7}$ & Very important & $(6,7,8)$ \\
$\widetilde{9}$ & Absolutely important & $(7,8,9)$ \\
$\widetilde{2}, \widetilde{4}, \widetilde{6}, \widetilde{8}$ & Intermediate values & $(\mathrm{x}-1, \mathrm{x}, \mathrm{x}+1)$ \\
$1 / \tilde{x}$ & Between two adjacent judgments & $(1 /(\mathrm{x}+1), 1 / \mathrm{x}, 1 /(\mathrm{x}-1)$ \\
\hline
\end{tabular}

Stage 3: Calculating local weight and global weight

Next, we calculated the global weights for the sub-factors. Global weights are calculated by multiplying the local weights of the sub-factors by the local weight of the factor to which they belong. 
We calculated the ConR for measuring how consistent the judgments have been relative to large samples of random judgments. If ConR $<0.1$, the judgment is acceptable; otherwise, a comparison matrix should be established [71].

Stage 4: Arriving at the priority using FAHP

Based on the proposed model, ten factors are affected by environmental performance in the food industry. Thus, the environmental performance evaluation model EPEM formula can be represented as follows:

$$
\text { EPEM }=\mathrm{W}_{1} \mathrm{~F}_{1}+\mathrm{W}_{2} \mathrm{~F}_{2}+\mathrm{W}_{3} \mathrm{~F}_{3}+\mathrm{W}_{4} \mathrm{~F}_{4}+\mathrm{W}_{5} \mathrm{~F}_{5}+\mathrm{W}_{6} \mathrm{~F}_{6}+\mathrm{W}_{7} \mathrm{~F}_{7}+\mathrm{W}_{8} \mathrm{~F}_{8}+\mathrm{W}_{9} \mathrm{~F}_{9}+\mathrm{W}_{10} \mathrm{~F}_{10}+\mathrm{W}_{11} \mathrm{~F}_{11}
$$

where $\mathrm{W}$ is the relative priority weightage; $\mathrm{F}$ is the relative weightage score for factory with respect to the tenth factor.

\section{Results}

\subsection{SEM Analysis Results}

We conducted structural equation modeling experiments to test the hypotheses. The results suggest that the hypothesized model fit the data well $\left(\chi^{2}=176, d f=156, \chi^{2} / d f=1.128, \mathrm{CFI}=0.997\right.$, IFI $>0.997$, and RMSEA $=0.014)$. Hypotheses 1 predicts that quality management is positively related to environmental performance. The results in Table 3 support this prediction $(p<0.01)$. Hypothesis 2 predicts that market orientation is positively related to environmental performance, which is also supported by the results $(p<0.01)$. Similarly, Hypothesis 3 predicts that innovation capability is positively related to environmental performance, and this hypothesis is also supported $(p<0.05)$.

Table 3. Results for the hypothesis.

\begin{tabular}{cccc}
\hline Causal Path & Hypothesis & Point Estimate & Hypothesis Support \\
\hline Quality management $\rightarrow$ Environmental performance & $\mathrm{H}_{1}$ & $0.642^{* *}$ & Yes \\
Market orientation $\rightarrow$ Environmental performance & $\mathrm{H}_{2}$ & $0.786^{* *}$ & Yes \\
Innovation capability $\rightarrow$ Environmental performance & $\mathrm{H}_{3}$ & $0.491^{*}$ & Yes \\
\hline
\end{tabular}

Note: "**" and "*" denote the significance levels of $1 \%$ and $5 \%$, respectively.

\subsection{FAHP Analysis Results}

The pairwise comparison matrices for the second-stage questionnaire were designed based on the results from the SEM analysis. A total of 18 valid questionnaires were completed and deemed suitable for FAHP analysis. Pairwise comparison matrices for the sub-factors, along with calculated local weights, are given in Tables 4-7. The global weights for the aspects and assessment items were calculated using the FAHP technique, consistency index (CI), and ConR, as shown in Table 8. Experts are most concerned about quality management, market orientation, and innovation capability, were most concerned about quality policy and quality assurance in terms of issues that affect environmental performance. Notably, in the FAHP calculation, all the judgment matrices were iterated to their ConR, which was less than 0.1 . To evaluate and predict environmental performance, we can substitute global weight results in formula (20) as follows:

$$
\begin{gathered}
E P E M=0.269 F_{1}+0.163 F_{2}+0.15 F_{3}+0.108 F_{4}+0.097 F_{5}+0.067 F_{6}+0.053 F_{7}+0.034 F_{8}+0.027 F_{9}+ \\
0.022 F_{10}+0.011 F_{11}
\end{gathered}
$$

Table 4. Local weights and pairwise comparison matrix of factors.

\begin{tabular}{ccccc}
\hline Factors & QM & MO & IC & Local Weights \\
\hline Quality management factors (QM) & $(1,1,1)$ & $(5.096,5.964,6.820)$ & $(3.050,3.992,4.892)$ & 0.662 \\
Market orientation factors (MO) & $(0.147,0.168,0.196)$ & $(1,1,1)$ & $(2.640,3.595,4.505)$ & 0.225 \\
Innovation capability factors (IC) & $(1.351,1.418,1.524)$ & $(7,8.20,6.690)$ & $(1,1,1)$ & 0.113 \\
\hline
\end{tabular}


Table 5. Local weights and pairwise comparison matrix of market orientation sub-factors.

\begin{tabular}{ccccc}
\hline Factors & MO1 & MO2 & MO3 & Local Weights \\
\hline Customer Orientation (MO1) & $(1,1,1)$ & $(3.372,4.466,5.518)$ & $(3.959,5.115,6.195)$ & 0.666 \\
Competitor Orientation (MO2) & $(0.181,0.224,0.297)$ & $(1,1,1)$ & $(2.496,3.577,4.619)$ & 0.235 \\
Inter-functional coordination (MO3) & $(0.161,0.196,0.253)$ & $(0.216,0.279,0.401)$ & $(1,1,1)$ & 0.099 \\
\hline
\end{tabular}

Table 6. Local weights and pairwise comparison matrix of innovation capability sub-factors.

\begin{tabular}{ccccc}
\hline Factors & IC1 & IC2 & IC3 & Local Weights \\
\hline Process Innovation (IC1) & $(1,1,1)$ & $(0.198,0.241,0.310)$ & $(0.171,0.202,0.252)$ & 0.101 \\
Knowledge and competency (IC2) & $(3.226,4.150,5.044)$ & $(1,1,1)$ & $(2.448,3.402,4.308)$ & 0.596 \\
Organizational support (IC3) & $(4.945,4.945,5.865)$ & $(0.232,0.294,0.409)$ & $(1,1,1)$ & 0.302 \\
\hline
\end{tabular}

Table 7. Local weights and pairwise comparison matrix of quality management sub-factors.

\begin{tabular}{ccccccc}
\hline Factors & QM1 & QM2 & QM3 & QM4 & QM5 & $\begin{array}{c}\text { Local } \\
\text { weights }\end{array}$ \\
\hline $\begin{array}{c}\text { Quality Assurance } \\
\text { (QM1) } \\
\text { Quality } \\
\begin{array}{c}\text { Improvement } \\
\text { (QM2) }\end{array}\end{array}$ & $(1,1,1)$ & $(2.238,2.893,3.480)$ & $(4.423,5.464,6.489)$ & $(2.026,2.796,3.492)$ & $(0.296,0.373,0.521)$ & 0.163 \\
$\begin{array}{c}\text { Quality Design } \\
\text { (QM3) }\end{array}$ & $(0.154,0.183,0.226)$ & $(0.219,0.275,0.382)$ & $(1,1,1)$ & $(0.148,0.176,0.217)$ & $(0.132,0.152,0.180)$ & 0.027 \\
$\begin{array}{c}\text { Quality Control } \\
\text { (QM4) }\end{array}$ & $(0.286,0.358,0.493)$ & $(0.214,0.276,0.395)$ & $(4.601,5.696,6.746)$ & $(1,1,1)$ & $(0.499,0.579,0.725)$ & 0.097 \\
$\begin{array}{c}\text { Quality Policy } \\
\text { (QM5) }\end{array}$ & $(1.919,2.684,3.380)$ & $(4.167,5.202,6.224)$ & $(5.555,6.565,7.571)$ & $(1.379,1.726,2.003)$ & $(1,1,1)$ & 0.269 \\
\hline
\end{tabular}

Table 8. Computed global weights for sub-factors, consistency index, and consistency Ratio.

\begin{tabular}{|c|c|c|c|c|c|c|}
\hline \multirow{2}{*}{$\begin{array}{l}\text { Criteria } \\
\text { Factors }\end{array}$} & \multirow{2}{*}{$\begin{array}{c}\text { Local } \\
\text { Weights }\end{array}$} & \multirow[b]{2}{*}{ Sub Factors } & \multicolumn{2}{|c|}{ FAHP } & \multirow[b]{2}{*}{$\mathrm{CI}$} & \multirow[b]{2}{*}{ CR } \\
\hline & & & $\begin{array}{c}\text { Local } \\
\text { Weights }\end{array}$ & $\begin{array}{c}\text { Global } \\
\text { Weights }\end{array}$ & & \\
\hline \multirow{5}{*}{$\begin{array}{c}\text { Quality } \\
\text { Management } \\
\text { (QM) }\end{array}$} & \multirow{5}{*}{$(0.662)$} & Quality Assurance (QM1) & 0.246 & 0.163 & \multirow{5}{*}{0.002} & \multirow{5}{*}{0.001} \\
\hline & & Quality Improvement (QM2) & 0.163 & 0.108 & & \\
\hline & & Quality Design (QM3) & 0.04 & 0.027 & & \\
\hline & & Quality Control (QM4) & 0.146 & 0.097 & & \\
\hline & & Quality Policy (QM5) & 0.405 & 0.269 & & \\
\hline \multirow{3}{*}{$\begin{array}{c}\text { Market } \\
\text { Orientation } \\
(\mathrm{MO})\end{array}$} & \multirow{3}{*}{$(0.225)$} & Customer Orientation (MO1) & 0.666 & 0.150 & \multirow{3}{*}{0.004} & \multirow{3}{*}{0.007} \\
\hline & & Competitor Orientation (MO2) & 0.235 & 0.053 & & \\
\hline & & Inter functional Coordination (MO3) & 0.099 & 0.022 & & \\
\hline Innovation & \multirow{3}{*}{$(0.113)$} & Process Innovation (IC1) & 0.101 & 0.011 & \multirow{3}{*}{0.003} & \multirow{3}{*}{0.005} \\
\hline \multirow{2}{*}{$\begin{array}{l}\text { Capability } \\
\text { (IC) }\end{array}$} & & Knowledge and Competency (IC2) & 0.596 & 0.067 & & \\
\hline & & Organizational Support (IC3) & 0.302 & 0.034 & & \\
\hline
\end{tabular}

\section{Conclusions}

Environmental problems have attracted substantial attention in many industries. In particular, the food industry will be directly affected by environmental impacts. Simultaneously, the food industry also makes more waste and pollution from all products, from raw material to disposal, and it is much more difficult to assess environmental performance related to this industry. Thus, the objective of this study is to investigate the criteria and factors affecting environmental performance and to create proper criteria to assess environmental performance in Thailand's food industry. The integrated SEM and FAHP approach was applied to eliminate uncertainty and ambiguity, which cannot be assessed with explicit numerical values of environmental performance evaluation. The SEM approach was employed to understand and identify criteria and sub-criteria that influence environmental performance and that are suitable to the Thailand food industry context. The FAHP instrument for 
gathering data was developed from SEM results, and then weighted and normalized for priority of factors. The model proposed that quality policy, quality assurance, knowledge and competency, quality improvement, quality control, customer orientation, organizational support, competitor orientation, quality design, process innovation, and inter-function coordination have a relatively strong influence effect on environmental performance. The relative weighting of the factors that we discussed above can be used as a reference and to support decision-making by managers or management teams when monitoring and determining environmental performance scores in their industry. The proposed model is an alternative way to evaluate method for evaluating environmental performance in the food industry and also supports the green industry concept that emphasizes sustainable development by balancing economic, social, innovation and environmental factors.

Acknowledgments: The authors would like to thank the reviewers for their constructive comments on this article.

Author Contributions: Anirut Pipatprapa, Hsiang-Hsi Huang, and Ching-Hsu Huang designed the research and methodology; Anirut Pipatprapa collected and analyzed the data; Anirut Pipatprapa, Hsiang-Hsi Huang, and Ching-Hsu Huang wrote and revised the paper; Hsiang-Hsi Huang, and Ching-Hsu Huang corrected the final manuscript.

Conflicts of Interest: The author declares no conflict of interest.

\section{References}

1. Wiengarten, F.; Pagell, M. The importance of quality management for the success of environmental management initiatives. Int. J. Prod. Econ. 2012, 140, 407-415. [CrossRef]

2. Menikpura, S.N.M.; Sang-Arun, J.; Bengtsson, M. Assessment of environmental and economic performance of waste-to-energy facilities in Thai cities. Renew. Energ. 2016, 86, 576-584. [CrossRef]

3. Rust, R.T.; Moorman, C.; Dickson, P.R. Getting return on quality: Revenue expansion, cost reduction, or both? J. Market. 2002, 66, 7-24. [CrossRef]

4. Basappaji, K.M.; Nagesha, N. Assessment of cleaner production level in agro based industries-A fuzzy logic approach. Energ. Proced. 2014, 54, 127-134. [CrossRef]

5. De Figueirêdo, M.C.B.; Rodrigues, G.S.; Caldeira-Pires, A.; de Freitas Rosa, M.; de Aragão, F.A.S.; Vieira, V.D.P.P.B.; Mota, F.S.B. Environmental performance evaluation of agro-industrial innovations-Part 1: Ambitec-life cycle, a methodological approach for considering life cycle thinking. J. Clean. Prod. 2010, 18, 1366-1375. [CrossRef]

6. National Economic and Social Development Board (NESDB). National Income of Thailand; Office of the National Economic and Social Development Board: Bangkok, Thailand, 2015.

7. Thailand Board of Investment (BOI). Thailand's Food Industry; Thailand Board of Investment: Bangkok, Thailand, 2014.

8. Department of Industrial Works (DIW). Green Industry Manual: The Guideline for Green Industry Promotion and Development, 5th ed.; Office of the permanent secretary for ministry of industry: Bangkok, Thailand, 2013; pp. 7-13.

9. Yigitcanlar, T.; Dur, F.; Dizdaroglu, D. Towards prosperous sustainable cities: A multiscalar urban sustainability assessment approach. Habitat Int. 2015, 45, 36-46. [CrossRef]

10. Sutthichaimethee, P.; Tanoamchard, W. Carrying capacity model of food manufacturing sectors for sustainable development from using environmental and natural resources of Thailand. J. Ecol. Eng. 2015, 16, 1-8. [CrossRef]

11. Burck, J.; Marten, F.; Bals, C. The Climate Change Performance Index, Result 2016; Climate Action Network Europe: Brussels, Belgium, 2015; p. 28.

12. Thai Food Processors' Association (TFPA). Thai Food Processors' Association Directory: 2013-2015; Cyber print Co., Ltd: Bangkok, Thailand, 2013; pp. 1-100.

13. Rimpeekool, W.; Seubsman, S.A.; Banwell, C.; Kirk, M.; Yiengprugsawan, V.; Sleigh, A. Food and nutrition labelling in thailand: A long march from subsistence producers to international traders. Food Policy 2015, 56, 59-66. [CrossRef] [PubMed]

14. Campos, L.M.S.; de Melo Heizen, D.A.; Verdinelli, M.A.; Cauchick Miguel, P.A. Environmental performance indicators: A study on ISO 14001 certified companies. J. Clean. Prod. 2015, 99, 286-296. [CrossRef] 
15. Lannelongue, G.; Gonzalez-Benito, J.; Gonzalez-Benito, O.; Gonzalez-Zapatero, C. Time compression diseconomies in environmental management: The effect of assimilation on environmental performance. J. Environ. Manag. 2015, 147, 203-212. [CrossRef] [PubMed]

16. Fleaca, E.; Fleaca, B.; Negoita, O.; Danalache, F. Raising the enterprises' environmental performance by taking advantage of business process modeling. Proced. Tech. 2015, 19, 333-340. [CrossRef]

17. Issa, I.I.; Pigosso, D.C.A.; McAloone, T.C.; Rozenfeld, H. Leading product-related environmental performance indicators: A selection guide and database. J. Clean. Prod. 2015, 108, 321-330. [CrossRef]

18. Hansen, A.P.; da Silva, G.A.; Kulay, L. Evaluation of the environmental performance of alternatives for polystyrene production in Brazil. Sci. Total Environ. 2015, 532, 655-668. [CrossRef] [PubMed]

19. Martin, M. Quantifying the environmental performance of an industrial symbiosis network of biofuel producers. J. Clean. Prod. 2015, 102, 202-212. [CrossRef]

20. Lee, K.-H.; Min, B.; Yook, K.-H. The impacts of carbon $\left(\mathrm{CO}_{2}\right)$ emissions and environmental research and development (R\&D) investment on firm performance. Int. J. Prod. Econ. 2015, 167, 1-11.

21. Lisi, I.E. Translating environmental motivations into performance: The role of environmental performance measurement systems. Manag. Acc. Resear. 2015, 29, 27-44. [CrossRef]

22. Neuteleers, S.; Engelen, B. Talking money: How market-based valuation can undermine environmental protection. Ecol. Econ. 2015, 117, 253-260. [CrossRef]

23. Chithambaranathan, P.; Subramanian, N.; Gunasekaran, A.; Palaniappan, P.K. Service supply chain environmental performance evaluation using grey based hybrid mcdm approach. Int. J. Prod. Econ. 2015, 166, 163-176. [CrossRef]

24. Malik, M.M.; Abdallah, S.; Hussain, M. Assessing supplier environmental performance: Applying analytical hierarchical process in the United Arab Emirates healthcare chain. Renew. Sustain. Energ. Rev. 2016, 55, 1313-1321. [CrossRef]

25. Larrán Jorge, M.; Herrera Madueño, J.; Martínez-Martínez, D.; Lechuga Sancho, M.P. Competitiveness and environmental performance in Spanish small and medium enterprises: Is there a direct link? J. Clean. Prod. 2015, 101, 26-37. [CrossRef]

26. Punniyamoorthy, M.; Mathiyalagan, P.; Parthiban, P. A strategic model using structural equation modeling and fuzzy logic in supplier selection. Expert Syst. Appl. 2011, 38, 458-474. [CrossRef]

27. Hair Joseph F, J.; Black, W.C.; Babin, B.J.; Anderson, R.E. Multivariate Data Analysis, 7th ed.; Pearson Prentice Hall: Upper Saddle River, NJ, USA, 2010; pp. 611-667.

28. Schumacker, R.E.; Lomax, R.G. A Beginner's Guide to Structural Equation Modeling, 3rd ed.; Taylor and Francis Group: New York, NY, USA, 2010; pp. 1-76.

29. Taha, H.A. Operations Research: An Introduction, 9th ed.; Pearson Prentice Hall: Upper Saddle River, NJ, USA, 2011.

30. Chang, Y.-F.; Ishii, H. Fuzzy multiple criteria decision making approach to assess the project quality management in project. Proced. Comp. Sci. 2013, 22, 928-936. [CrossRef]

31. Ghadimi, P.; Azadnia, A.H.; Mohd Yusof, N.; Mat Saman, M.Z. A weighted fuzzy approach for product sustainability assessment: A case study in automotive industry. J. Clean. Prod. 2012, 33, 10-21. [CrossRef]

32. Tang, Y.C.; Lin, T.W. Application of the fuzzy analytic hierarchy process to the lead-free equipment selection decision. Int. J. Bus. Syst. Resear. 2011, 5, 35-56. [CrossRef]

33. Celik, M.; Deha Er, I.; Ozok, A.F. Application of fuzzy extended ahp methodology on shipping registry selection: The case of Turkish maritime industry. Expert Syst. Appl. 2009, 36, 190-198. [CrossRef]

34. Kahraman, C.; Ruan, D.; Doğan, I. Fuzzy group decision-making for facility location selection. Inform. Sci. 2003, 157, 135-153. [CrossRef]

35. Mikhailov, L. Deriving priorities from fuzzy pairwise comparison judgements. Fuzzy Set. Syst. 2003, 134, 365-385. [CrossRef]

36. Wang, Y.-M.; Chin, K.-S. Fuzzy analytic hierarchy process: A logarithmic fuzzy preference programming methodology. Int. J. Approximate Reason. 2011, 52, 541-553. [CrossRef]

37. Büyüközkan, G.; Çifçi, G.; Güleryüz, S. Strategic analysis of healthcare service quality using fuzzy AHP methodology. Expert Syst. Appl. 2011, 38, 9407-9424. [CrossRef]

38. Büyüközkan, G.; Çifçi, G. A combined fuzzy ahp and fuzzy topsis based strategic analysis of electronic service quality in healthcare industry. Expert Syst. Appl. 2012, 39, 2341-2354. [CrossRef] 
39. Luning, P.A.; Marcelis, W.J. A conceptual model of food quality management functions based on a techno-managerial approach. Trends Food Sci. Tech. 2007, 18, 159-166. [CrossRef]

40. Dora, M.; Kumar, M.; van Goubergen, D.; Molnar, A.; Gellynck, X. Food quality management system: Reviewing assessment strategies and a feasibility study for European food small and medium-sized enterprises. Food Control 2013, 31, 607-616. [CrossRef]

41. Scott, B.S.; Wilcock, A.E.; Kanetkar, V. A survey of structured continuous improvement programs in the canadian food sector. Food Control 2009, 20, 209-217. [CrossRef]

42. Boiral, O.; Henri, J.F. Modelling the impact of ISO 14001 on environmental performance: A comparative approach. J. Environ. Manag. 2012, 99, 84-97. [CrossRef] [PubMed]

43. Hajmohammad, S.; Vachon, S.; Klassen, R.D.; Gavronski, I. Lean management and supply management: Their role in green practices and performance. J. Clean. Prod. 2013, 39, 312-320. [CrossRef]

44. Yang, M.G.; Hong, P.; Modi, S.B. Impact of lean manufacturing and environmental management on business performance: An empirical study of manufacturing firms. Int. J. Prod. Econ. 2011, 129, 251-261. [CrossRef]

45. Chiou, T.-Y.; Chan, H.K.; Lettice, F.; Chung, S.H. The influence of greening the suppliers and green innovation on environmental performance and competitive advantage in taiwan. Transport. Res. E Logist. Transport. Rev. 2011, 47, 822-836. [CrossRef]

46. Lin, R.-J.; Tan, K.-H.; Geng, Y. Market demand, green product innovation, and firm performance: Evidence from Vietnam motorcycle industry. J. Clean. Prod. 2013, 40, 101-107. [CrossRef]

47. Gholami, R.; Sulaiman, A.B.; Ramayah, T.; Molla, A. Senior managers' perception on green information systems (is) adoption and environmental performance: Results from a field survey. Inform. Manag. 2013, 50, 431-438. [CrossRef]

48. Zehir, C.; Ertosun, Ö.G.; Zehir, S.; Müceldilli, B. Total quality management practices' effects on quality performance and innovative performance. Proced. Soc. Behav. Sci. 2012, 41, 273-280. [CrossRef]

49. Fayzollahi, S.; Shirmohammadi, A.; Latifian, B. The impact of environmental factors on total quality management and firm performance: Evidence from industrial enterprises in Iran. Int. Resear. J. Appl. Basic Sci. 2013, 4, 3237-3245.

50. Slater, S.F.; Narver, J.C. Market orientation and the learning organization. J. Market. 1995, 59, 63-74. [CrossRef]

51. Charles, L.; Joel, C.; Samwel, K.C. Market orientation and firm performance in the manufacturing sector in kenya. Eur. J. Bus. Manag. 2012, 4, 20-27.

52. Kumar, K.; Subramanian, R.; Yauger, C. Examining the market orientation performance relationship: A context-specific study. J. Manag. 1998, 24, 201-233. [CrossRef]

53. Chen, Y.; Tang, G.; Jin, J.; Li, J.; Paillé, P. Linking market orientation and environmental performance: The influence of environmental strategy, employee's environmental involvement, and environmental product quality. J. Bus. Ethics 2014. [CrossRef]

54. Lawson, B.; Samson, D. Developing innovation capability in organizations a dynamic capabilities approach. Int. J. Innovat. Manag. 2001, 5, 377-400. [CrossRef]

55. Chang, S.-C.; Lee, M.-S. The linkage between knowledge accumulation capability and organizational innovation. J. Knowl. Manag. 2008, 12, 3-20. [CrossRef]

56. Lin, R.-J.; Chen, R.-H.; Chiu, K.; Chiu, K.K.-S. Customer relationship management and innovation capability: An empirical study. Ind. Manag. Data Syst. 2010, 110, 111-133. [CrossRef]

57. Saunila, M.; Ukko, J. Facilitating innovation capability through performance measurement: A study of Finnish SMES. Manag. Resear. Rev. 2013, 36, 991-1010. [CrossRef]

58. Cheng, C.C.J.; Yang, C.-L.; Sheu, C. The link between eco-innovation and business performance: A taiwanese industry context. J. Clean. Prod. 2014, 64, 81-90. [CrossRef]

59. Sezen, B.; Çankaya, S.Y. Effects of green manufacturing and eco-innovation on sustainability performance. Proced. Soc. Behav. Sci. 2013, 99, 154-163. [CrossRef]

60. Ar, I.M. The impact of green product innovation on firm performance and competitive capability: The moderating role of managerial environmental concern. Proced. Soc. Behav. Sci. 2012, 62, 854-864. [CrossRef]

61. Diakaki, C.; Grigoroudis, E.; Stabouli, M. A risk assessment approach in selecting environmental performance indicators. Manag. Environ. Quality Int. J. 2006, 17, 126-139. [CrossRef] 
62. Perotto, E.; Canziani, R.; Marchesi, R.; Butelli, P. Environmental performance, indicators and measurement uncertainty in ems context: A case study. J. Clean. Prod. 2008, 16, 517-530. [CrossRef]

63. Rowland-Jones, R.; Pryde, M.; Cresser, M. An evaluation of current environmental management systems as indicators of environmental performance. Manag. Environ. Quality Int. J. 2005, 16, 211-219. [CrossRef]

64. Innami, Y.; Koizumi, R. Structural equation modeling in educational research: A primer. In Application of Structural Equation Modeling in Educational Research and Practice; Sense publishers: The Netherlands, 2013; Volume 7, pp. 23-51.

65. Phan, T.N.; Baird, K. The comprehensiveness of environmental management systems: The influence of institutional pressures and the impact on environmental performance. J. Environ. Manag. 2015, 160, 45-56. [CrossRef] [PubMed]

66. Teo, T.; Tsai, L.T.; Yang, C.-C. Applying structural equation modeling (sem) in educational research: An introduction. In Application of Structural Equation Modeling in Educational Research and Practice; Sense publishers: The Netherlands, 2013; Volume 7, pp. 1-21.

67. Dağdeviren, M.; Yüksel, İ. Developing a fuzzy analytic hierarchy process (AHP) model for behavior-based safety management. Inform. Sci. 2008, 178, 1717-1733. [CrossRef]

68. Wang, J.; Ding, D.; Liu, O.; Li, M. A synthetic method for knowledge management performance evaluation based on triangular fuzzy number and group support systems. Appl. Soft Comp. 2016, 39, 11-20. [CrossRef]

69. Shen, L.; Olfat, L.; Govindan, K.; Khodaverdi, R.; Diabat, A. A fuzzy multi criteria approach for evaluating green supplier's performance in green supply chain with linguistic preferences. Resour. Conservat. Recycl. 2013, 74, 170-179. [CrossRef]

70. Dong, M.; Li, S.; Zhang, H. Approaches to group decision making with incomplete information based on power geometric operators and triangular fuzzy ahp. Expert Syst. Appl. 2015, 42, 7846-7857. [CrossRef]

71. Kabir, M.A.; Latif, H.H.; Sarker, S. A multi-criteria decision-making model to increase productivity: AHP and fuzzy AHP approach. Int. J. Intell. Syst. Tech. Appl. 2013, 12, 208-229. [CrossRef]

(c) 2016 by the authors; licensee MDPI, Basel, Switzerland. This article is an open access article distributed under the terms and conditions of the Creative Commons by Attribution (CC-BY) license (http://creativecommons.org/licenses/by/4.0/). 